\title{
Indonesia's Foreign Policy in Pacific Island Countries during Joko Widodo Era 2014- 2019: An Adaptive Action?
}

\author{
Kebijakan Luar Negeri Indonesia di \\ Negara-Negara Kepulauan Pasifik Era \\ Joko Widodo 2014-2019: Sebuah Tindakan \\ Adaptif?
}

\author{
Vrameswari Omega Wati \\ Universitas Katolik Parahyangan \\ Stanislaus Risadi Apresian \\ University of Leeds \\ Elisabeth A. Satya Dewi \\ Universitas Katolik Parahyangan
}

\begin{abstract}
ABSTRAK
Istilah 'Pacific Elevation' muncul pertama kali ketika penyelenggaraan Pacific Exposition pada 2019 lalu di Auckland, Selandia Baru. Konsep baru ini diperkenalkan oleh Menteri Luar Negeri, Retno Marsudi sebagai istilah yang merujuk pada era baru kemitraan yang lebih kuat antara Indonesia dengan negara-negara Kepulauan Pasifik. Kegiatan yang dimanfaatkan untuk membahas berbagai peluang kerja sama ini merupakan salah satu bentuk realisasi kebijakan 'Look East' oleh Indonesia dengan memberikan perhatian lebih melalui berbagai keterlibatannya di negara-negara Kepulauan Pasifik. Kajian ini menggunakan metode kualitatif dengan teknik pengumpulan data melalui studi literatur dan diskusi kelompok terarah. Artikel ini bertujuan untuk menganalisis dan memaparkan realisasi kebijakan luar negeri Indonesia di negara-negara Kepulauan Pasifik merupakan tindakan adaptif sebagai respons dari perkembangan yang terjadi di lingkup eksternal. Hasil kajian ini menunjukkan bahwa perkembangan di negara-negara Kepulauan Pasifik seperti seringnya pergantian kepemimpinan yang terjadi, manuver politik Gerakan Persatuan Pembebasan untuk Papua Barat, dan disuarakannya isu Papua oleh beberapa negara di Kepulauan Pasifik dalam sidang PBB mendorong pemerintah Indonesia mengeluarkan kebijakan adaptif untuk mengatasi potensi ancaman yang diterima dengan cara meningkatkan keterlibatan yang lebih intensif di kawasan Kepulauan Pasifik.
\end{abstract}

Kata-kata kunci: Kebijakan luar negeri, Adaptif, Papua, Kepulauan Pasifik

The term 'Pacific Elevation' first appeared in the Pacific Exposition event in 2019 in Auckland, New Zealand. The Minister of Foreign Affairs, Retno Marsudi, introduced this new concept as a term that refers to a new era of stronger partnerships between Indonesia and Pacific Island Countries (PIC). The activity used to discuss various opportunities for cooperation is one of the realizations of the 'Look East' policy by giving more attention to Indonesia's various engagements in the PICs. This study employs a qualitative method with data collection techniques through literature study and focus group discussions. This article aims to analyze and explain that Indonesia's foreign policy in PICs is an adaptive action in response to developments in the external environment. The results of this study indicate that developments in PICs such as frequent leadership changes, political maneuvering of the United Liberation Movement of West Papua, and voicing the issue of Papua by several PICs in the UN forum encouraged the Indonesian government to issue an adaptive policy to overcome the potential threats received by Indonesia by increasing more intensive involvement in the region of Pacific Islands.

Keywords: Foreign policy, Adaptive, Papua, Pacific Islands 
Konstitusi yang tertulis dalam Undang-Undang Dasar Republik Indonesia tahun 1945 menegaskan bahwa bangsa Indonesia memiliki mandat untuk ikut melaksanakan ketertiban dunia berdasarkan kemerdekaan, perdamaian abadi, dan keadilan sosial. Amanat konstitusional ini dilaksanakan oleh pemerintah Indonesia melalui politik luar negeri yang berlandaskan prinsip "bebas-aktif". Prinsip ini mengandung makna bahwa politik luar negeri Indonesia tidak memihak kekuatan besar mana pun dalam sistem internasional, tetapi tetap berperan aktif dan memiliki pendirian teguh guna mencapai kepentingan nasionalnya. Pelaksanaan politik luar negeri ini pun diatur dalam UndangUndang Republik Indonesia Nomor 37 Tahun 1999 tentang Hubungan Luar Negeri. Setiap pergantian rezim di Indonesia, pelaksanaan kebijakan luar negeri dari masa ke masa memiliki ciri khasnya masing-masing, baik itu mengalami kontinuitas maupun perubahan (Anwar 2010, 139). Pada masa kepemimpinan Presiden Joko Widodo (Jokowi), memperkuat peran Indonesia melalui kerja sama global dan regional dalam rangka membangun saling pengertian, memajukan demokrasi dan HAM, perdamaian dunia, meningkatkan Kerjasama Selatan-Selatan (KSS), dan mengatasi masalah-masalah global yang mengancam umat manusia merupakan komitmen yang ingin dicapai seperti yang tertuang dalam RPJMN 2015-2019 (Bappenas 2014, 89; Kementerian Luar Negeri 2015, 43). Dalam 10 tahun terakhir, kebijakan luar negeri Indonesia berpedoman pada dua aspek (Bappenas 2014). Pertama, untuk mendukung pencapaian kepentingan nasionalnya sambil terus berkontribusi secara aktif dalam forum internasional. Kedua, keterlibatan Indonesia dapat bermanfaat bagi masyarakat internasional. Implementasi kebijakan luar negeri Indonesia tentunya harus dapat menghadapi situasi politik internasional yang bersifat dinamis sehingga membutuhkan peran yang kuat dalam mencapai kepentingan nasional.

Dalam kepemimpinan Jokowi pada periode pertama, terdapat empat prioritas dalam melakukan kebijakan luar negeri, yaitu (1) memperkuat identitas Indonesia sebagai negara maritim dalam membangun kerja sama internasional, (2) meningkatkan peran global dengan memperkuat diplomasi kekuatan menengah, (3) memperluas keterlibatan regional di kawasan Indo-Pasifik, dan (4) memprioritaskan kepentingan masyarakat dalam perumusan 
dan implementasi kebijakan luar negeri (Connely 2014, 6). Dalam menjalankan kebijakan luar negerinya, pemerintah membentuk lingkaran konsentris untuk memastikan pencapaian tujuan nasional Indonesia. Lingkaran konsentris pertama menempatkan ASEAN sebagai pilar utama kebijakan luar negeri Indonesia berdasarkan pertimbangan geostrategis. Akan tetapi, ketika kepemimpinan Mochtar Kusumaatmadja, mantan menteri luar negeri era Soeharto, kebijakan luar negeri Indonesia tidak hanya terbatas pada Asia Tenggara saja melainkan mulai memerhatikan wilayah Kepulauan Pasifik (Bandoro 2014). Menurut Mochtar Kusumaatmadja, wilayah tersebut dapat menjadi sumber ketidakstabilan (Bandoro 2014). Karena alasan ini, Indonesia berusaha memperluas keterlibatannya dengan menjadi pengamat di Forum Pasifik Selatan dan mulai mengeksplorasi hubungan dengan negara-negara di Kepulauan Pasifik. ${ }^{1}$

Sejarah hubungan Indonesia dengan negara-negara di Kepulauan Pasifik dimulai pada akhir tahun 1970-an. Pada saat itu, wilayah ini mendapat perhatian besar dari para pembuat kebijakan luar negeri sehubungan dengan masalah Timor Timur (Bandoro 2014, 21). Oposisi terhadap integrasi Timor Timur ke Indonesia datang dari beberapa negara di Kepulauan Pasifik. Situasi ini membuat pemerintah Indonesia kemudian mengirim utusan khusus ke wilayah Kepulauan Pasifik. Mempertimbangkan sejarah dinamika hubungan Indonesia dan situasi yang terjadi di kawasan Kepulauan Pasifik, pemerintah Indonesia kemudian mulai memperhitungkan potensi ancaman dari Timur (Pasifik) terkait dengan kedaulatan Indonesia.

Secara umum, Indonesia memandang Kepulauan Pasifik sebagai wilayah yang relatif damai karena konflik skala besar hampir tidak pernah terjadi (Bandoro 2014, 21). Sebagian besar negara di Kepulauan Pasifik kecuali Australia dan Selandia Baru memiliki pembangunan yang tertinggal, pertumbuhan ekonomi yang rendah, dan populasiyang sedikit (Kaikai 2015,4). Walau demikian, negara-negara ini diberkahi dengan sumber daya alam dan

1 Forum Pasifik Selatan telah bertransformasi menjadi Forum Kepulauan Pasifik. Dalam kajian ini istilah Negara Kepulauan Pasifik digunakan untuk merujuk ke negara-negara di kawasan Pasifik Selatan. Penggunaan istilah kawasan Pasifik Selatan masih diperdebatkan karena adanya anggapan terkait stigma posisi asimetris terhadap negara 'selatan' sebagai negara ketiga. 
memiliki suara (one state one vote) dalam organisasi internasional seperti PBB (Hannesson 2008; Stringer 2006). Terlepas dari karakteristik geografisnya, dinamika politik di Kepulauan Pasifik mengharuskan Indonesia untuk terus mengikuti perkembangan yang terjadi. Selain sebagai upaya untuk menunjukkan konsistensi pemerintah Indonesia dalam menerapkan kebijakan 'Look East', di era kepemimpinan Jokowi, pemerintah Indonesia juga gencar untuk memperkuat kerja sama ekonomi dan perdagangan dengan negara-negara di Kepulauan Pasifik. Atas dasar pertimbangan politis dan ekonomi, pemerintah Indonesia menganggap negaranegara di Kepulauan Pasifik sebagai mitra strategis.

Artikel ini bertujuan untuk menyajikan suatu analisis yang menitikberatkan pada bagaimana perkembangan pada lingkup eksternal dapat memengaruhi kebijakan luar negeri suatu negara sehingga mendorong tindakan adaptif untuk meminimalisasi risiko sekaligus mengoptimalkan peluang yang dihasilkan dari perubahan yang terjadi. Kajian ini menunjukkan bahwa kebijakan luar negeri Indonesia terhadap negara-negara Kepulauan Pasifik selama masa kepresidenan Jokowi merupakan sebuah sikap adaptif yang dilakukan terutama sebagai respons atas perubahan iklim politik di Kepulauan Pasifik yang kemudian menempatkan negara-negara ini sebagai salah satu mitra strategis Indonesia.

\section{Kebijakan Luar Negeri, Kepentingan Nasional, dan Tindakan Adaptif}

Perkembangan teori kebijakan luar negeri tidak terlepas dari karya Snyder et al. (1954) yang membahas pengambilan keputusan sebagai pendekatan dalam studi politik internasional, James N. Rosenau (1966) yang menulis tentang 'Pra-teori dan Teori Kebijakan Luar Negeri', dan Harold Sprout dan Margaret Sprout (1956) yang membawa ide 'psiko-lingkungan' dari individu atau kelompok dalam memengaruhi proses pengambilan keputusan kebijakan luar negeri. Ketiga karya yang mengawali pengembangan teori tentang kebijakan luar negeri kemudian menginspirasi Valerie Hudson untuk mengembangkan studi tentang Analisis Kebijakan Luar Negeri. 
Kajian ini berangkat dari pengertian dasar mengenai kebijakan luar negeri. Hudson (2014) berpendapat bahwa kebijakan luar negeri adalah strategi dan pendekatan yang dipilih oleh pemerintah nasional untuk mencapai tujuannya dalam hubungannya dengan entitas eksternal, termasuk keputusan untuk tidak mengambil apa pun. Biasanya keputusan yang diambil dilihat sebagai upaya untuk memberikan pengaruh terhadap aktor-aktor atau entitas eksternal, tetapi tidak menutup kemungkinan juga bahwa keputusan yang diambil oleh pemerintah ditargetkan kepada entitas domestik tetapi memiliki konsekuensi terhadap pihak eksternal. Hill $(2016,4)$ mengungkapkan bahwa kebijakan luar negeri merupakan segala aktivitas eksternal resmi yang dilakukan oleh aktor independen (biasanya negara, tetapi tidak eksklusif bagi negara saja). Berdasarkan dua definisi yang dikemukakan oleh Hill (2016) dan Hudson (2014), ada tiga hal yang perlu ditekankan. Pertama, sebuah kebijakan memiliki akar pada konsep pilihan sehingga negara harus menentukan tindakan atau membuat keputusan-keputusan untuk mencapai suatu tujuan (Perwita dan Yani 2006, 48). Kedua, kebijakan yang ditujukan ke luar wilayah negara atau ditargetkan untuk entitas eksternal menunjukkan adanya kontrol atau batasan terhadap kedaulatan yang dimiliki suatu negara. Ketiga, konsep yang melekat pada kebijakan luar negeri tidak akan pernah terlepas dari kepentingan nasional sebuah negara.

Nuechterlein $(1976,247)$ menyatakan bahwa kepentingan nasional adalah kebutuhan dan keinginan yang dimiliki oleh satu negara berdaulat dalam kaitannya dengan negara berdaulat lainnya yang merupakan bagian dari lingkungan eksternal. Pemahaman ini dapat dijabarkan dalam tiga poin. Pertama, kepentingan nasional merupakan hasil dari proses politik yang menekankan pentingnya untuk memerhatikan isu yang spesifik. Kedua, aktor yang dapat memutuskan kepentingan nasional hanyalah negara berdaulat yang independen. Ketiga, pengertian Nuechterlein (1976) mengenai kepentingan nasional memisahkan antara lingkungan eksternal dan domestik, hal itu menunjukkan bahwa dalam menentukan kepentingan nasionalnya, negara masih mempertimbangkan interaksi mereka dengan lingkungan eksternal. Lebih lanjut, Nuechterlain $(1976,248)$ berpendapat ada empat kepentingan nasional mendasar yang dapat menjadi pertimbangan formulasi 
kebijakan luar negeri, antara lain, (1) kepentingan pertahanan yang merujuk pada perlindungan negara dan warganya dalam menghadapi ancaman eksternal dari negara lain; (2) kepentingan ekonomi yang merujuk pada peningkatan kesejahteraan ekonomi negara dalam hubungannya dengan negara-negara lain; (3) kepentingan ketertiban dunia yang mengacu pada pemeliharaan perdamaian dan keamanan dalam sistem internasional; dan (4) kepentingan ideologis yang merujuk pada perlindungan nilai-nilai yang diyakini oleh negara sebagai hal yang baik secara universal. Tingkatan kepentingan nasional dapat terbagi menjadi empat level, yaitu masalah kelangsungan hidup (survival), vital, utama (major), dan periferal. Tingkatan ini dibuat untuk menetapkan urgensi dari setiap kepentingan nasional yang diformulasikan. Ada 8 faktor yang dapat dipertimbangkan dalam memutuskan tingkat urgensi dari setiap kepentingan nasional yaitu, kedekatan bahaya (proximity of danger), sifat ancaman, kepentingan ekonomi, keterikatan sentimental, tipe pemerintahan, efek pada keseimbangan kekuasaan, prestise nasional, dan sikap aliansi dan pertemanan (Nuechterlein, 1976). Pada akhirnya, proses pengambilan keputusan akan bergantung pada bagaimana negara melihat kepentingan nasional mereka dan sikap atau kebijakan yang diambil ditentukan oleh para pemimpin politik.

Rosenau (1974) mengembangkan suatu teori kebijakan luar negeri dengan memusatkan perhatiannya pada analisis perspektif adaptif yang menggambarkan pembuatan kebijakan luar negeri yang diambil oleh para pembuat keputusan sebagai sebuah respons terhadap perubahan yang terjadi di lingkungan internal maupun eksternal. Pada hakikatnya, menurut Rosenau, kebijakan luar negeri yang diambil oleh negara merupakan tindakan adaptif untuk menyesuaikan dengan perubahan yang terjadi di lingkungannya dengan tujuan untuk mempertahankan kepentingan nasional. Setiap perilaku kebijakan luar negeri yang dilakukan oleh pemerintah dianggap adaptif ketika mengatasi atau mendorong perubahan dalam lingkungan eksternal yang bertujuan untuk mempertahankan struktur esensial negara (Rosenau 1970, 367). Dalam hal ini, struktur esensial yang dimaksud meliputi pemerintahan, ekonomi, struktur sosial, dan physical base yang membentuk pola keterkaitan satu dengan yang lain (Rosenau, 1974). Kebijakan luar negeri yang adaptif juga dapat dipahami 
sebagai perilaku satu negara dalam merespons perubahan yang hanya terjadi di lingkungan eksternal saja.

Rosenau (1974) berpendapat bahwa dari perspektif adaptif, lingkungan eksternal tidak mencakup sistem internasional secara keseluruhan, tetapi negara hanya perlu menyesuaikan perubahanperubahan di lingkungan yang memiliki pengaruh besar (salient environment) pada struktur esensial mereka. Perubahan merupakan dimensi utama dari kebijakan yang adaptif. Jika tidak ada perubahan, negara tidak perlu beradaptasi. Adaptasi dapat terjadi ketika perkembangan domestik membawa suatu kebutuhan dan hasrat baru dalam kaitannya dengan kondisi lingkungan eksternal, atau ketika perkembangan di lingkungan eksternal berpotensi mengancam struktur esensial negara (Rosenau 1974, 372). Perubahan-perubahan di lingkungan eksternal meliputi perubahan pada personel, perubahan politik, dan sosial ekonomi. Perubahan personel yang dimaksud misalnya terdapat pergantian kepemimpinan dalam pemerintahan dari suatu negara yang kemudian memiliki dampak pada negara lain sehingga perlu melakukan adaptasi untuk menyesuaikan dengan perubahan lingkungan eksternalnya (Rosenau 1970, 375). Sementara itu, perubahan politik yang dimaksudkan adalah perubahan dalam persyaratan, kemampuan, dan keterbatasan peran pemerintah dalam mengatur negaranya maupun dalam hubungannya dengan negara-negara lain. Dalam menanggapi perubahan di lingkungan eksternal yang memiliki dampak signifikan pada suatu negara maka para pengambil keputusan harus menyesuaikan sikap, sumber daya, dan interaksi terhadap lingkungan eksternalnya untuk meminimalisasi risiko dan mengoptimalkan peluang yang ada dari perubahan-perubahan yang terjadi (Rosenau 1970, 377). Terdapat empat pola adaptasi kebijakan luar negeri yang dikembangkan oleh Rosenau (1981), yaitu (1) preservative adaptation (responsif terhadap perubahan dan permintaan dalam lingkungan internal dan eksternal); (2) acquiescent adaptation (responsif terhadap perubahan dan permintaan eksternal); (3) intransigent adaptation (responsif terhadap permintaan dan perubahan internal); dan (4) promotive adaptation (tidak responsif baik terhadap perubahan dan permintaan internal dan eksternal). 
Indonesia's Foreign Policy in Pacific Island Countries during Joko Widodo Era 2014-2019: An Adaptive Action?

\section{Karakteristik Kebijakan Luar Negeri Joko Widodo: Pro-People Diplomacy}

Joko Widodo yang menggantikan Presiden Susilo Bambang Yudhoyono merupakan Presiden Republik Indonesia ketujuh yang memiliki latar belakang berbeda dari para pendahulunya. Tidak memiliki latar belakang militer dan bukan berasal dari keluarga yang memiliki keterkaitan dengan sejarah perpolitikan di Indonesia menjadikan Jokowi populer khususnya di kalangan masyarakat wong cilik. Jokowi dipandang sebagai harapan baru di era demokrasi politik Indonesia. Program blusukan-nya menggambarkan dirinya sebagai orang yang rendah hati dan prorakyat yang pada akhirnya menuntunnya dalam memformulasikan orientasi kebijakan luar negeri Indonesia. Ketika masuk dalam bursa pemilihan presiden, keterampilan dan pengetahuan Joko Widodo dalam hubungan internasional dan isu keamananpertahanan acapkali diragukan.

Menurut Weatherbee (2017), orientasi kebijakan luar negeri Indonesia selama pemerintahan Jokowi berbedajika dibandingkan dengan pemimpin sebelumnya yakni Susilo Bambang Yudhoyono (SBY). Di bawah kepemimpinan SBY, kebijakan luar negeri Indonesia mencerminkan karakter high profile yang menunjukkan kekuatan Indonesia sebagai negara middle power yang secara aktif terlibat dalam berbagai forum multilateral dan acara internasional (Weatherbee 2017, 163). Indonesia berusaha mencapai status sebagai pemimpin di Asia Tenggara tidak hanya melalui keterlibatan aktifnya dalam organisasi regional ASEAN, tetapi juga berupaya untuk mengambil posisi dan peran yang lebih kuat dengan berpartisipasi dalam forum tingkat tinggi seperti APEC, G-20, dan PBB (Poole 2015). Sebagaimana dinyatakan oleh Acharya $(2014,2)$, di bawah pemerintahan SBY, Indonesia dipandang sebagai kekuatan regional dengan kepentingan dan kepedulian global.

Sementara itu dalam relasinya dengan dunia internasional, seperti yang dikemukakan oleh Weatherbee (2017), selama hampir satu periode Jokowi terlihat tidak tertarik untuk terlibat lebih aktif dalam menjalankan kebijakan luar negeri kecuali jika terhubung dengan agenda domestik yang menjadi perhatiannya. 
Dalam merancang arah kebijakan luar negeri Indonesia, Jokowi memprioritaskan perlindungan warga negara Indonesia di luar negeri sebagai diplomasi garis depan dan juga menekankan pelaksanaan diplomasi ekonomi untuk mendukung program pembangunan infrastruktur domestik. Karakteristik kebijakan luar negeri Jokowi digambarkan sebagai inward-looking dengan jargon diplomasi pro-rakyat. Arah kebijakan luar negeri di bawah Jokowi dimaksudkan agar dapat memberikan kontribusi langsung kepada masyarakat Indonesia. Adapun pendapat lain yang menyatakan bahwa Indonesia masih melanjutkan kebijakan luar negeri secara aktif walaupun dengan tingkat partisipasi yang lebih rendah dibandingkan era SBY (Rosyidin 2017). Misalnya, Indonesia terpilih sebagai Anggota Tidak Tetap DK PBB untuk 2019-2020 mewakili wilayah Asia Pasifik dan tetap berkontribusi untuk menjaga perdamaian dan keamanan internasional dengan mengirimkan pasukan penjaga perdamaian dan bantuan kemanusiaan seperti ke Rakhine, Cox's Bazaar, dan Gaza. Dalam kaitannya dengan Kepulauan Pasifik, Jokowi tetap melanjutkan kebijakan 'Look East Policy' yang memprioritaskan kawasan ini dalam politik luar negeri Indonesia, misalnya dengan memberikan bantuan bencana kepada Fiji dan Vanuatu dengan jumlah yang besar. Tetapi yang membedakan adalah keterlibatan Indonesia untuk menggandeng negara-negara Kepulauan Pasifik menjadi lebih intens. Terlihat pada penyelenggaraan Pacific Exposition pada 2019 lalu di Auckland, Selandia Baru di mana pada saat itu, Retno Marsudi memperkenalkan istilah Pacific Elevation yang merujuk pada era kemitraan baru bagi Indonesia dan Pasifik (Marsudi 2019). Di bawah kepemimpinan Jokowi selama satu periode ini, Indonesia adalah kekuatan regional dengan keterlibatan global yang selektif (Rosyidin 2017).

\section{Kebijakan Luar Negeri Indonesia di Kepulauan Pasifik sebagai Bentuk Tindakan Adaptif}

Kebijakan luar negeri Indonesia terhadap negara-negara di kawasan Kepulauan Pasifik dianalisis sebagai tindakan yang adaptif. Kebijakan yang sering disebut oleh Kementerian Luar Negeri sebagai 'Look East Policy' ini menekankan keterlibatan 
Indonesia yang lebih mendalam dengan negara-negara di Kepulauan Pasifik dan berbagai inisiatif regionalnya, seperti Melanesian Spearhead Group (MSG), Forum Kepulauan Pasifik (PIF), dan Forum Pengembangan Kepulauan Pasifik (PIDF) (Cornock 2018). Selama satu periode, realisasi kebijakan luar negeri Jokowi di Kepulauan Pasifik cenderung menunjukkan tindakan yang diperuntukkan untuk merespons perkembangan di lingkungan eksternal. Faktor-faktor seperti kedekatan geografis, kesamaan etnis Melanesia, dan keanekaragaman budaya menjadi alasan umum yang digunakan dalam membangun kemitraan antara Indonesia dengan negara-negara di Kepulauan Pasifik. Tidak hanya itu, Indonesia juga memiliki visi untuk mengambil peran dalam menjaga stabilitas dan keamanan regional serta menjadi $h u b$ atau penghubung antara negara-negara di Kepulauan Pasifik dan Asia Tenggara pada khususnya. Selain itu, Indonesia melihat negara-negara di Kepulauan Pasifik sebenarnya memiliki potensi dalam mengembangkan sumber daya alam dan kemaritiman, menjaga stabilitas regional, dan meningkatkan kerja sama di beberapa sektor seperti ekonomi, lingkungan, atau ancaman nontradisional seperti bencana alam.

Walaupun demikian, kondisi politik domestik dan lemahnya pemerintahan di negara-negara Kepulauan Pasifik yang memiliki potensi ketidakstabilan kawasan menimbulkan persepsi pada masyarakat internasional, termasuk Indonesia bahwa negara-negara di Kepulauan Pasifik rentan terhadap gejolak politik (Bandoro 2014). Ketidakstabilan politik domestik erat kaitannya dengan perubahan kepemimpinan yang sering terjadi di negara-negara Kepulauan Pasifik (International Institute for Democracy and Electoral Assistance 2015, 1). Dampak dari seringnya pergantian kepemimpinan tidak hanya mengganggu pembangunan fisik dan manusia di negara-negara Kepulauan Pasifik karena implementasi program kerja jangka panjang tidak dapat tercapai, tetapi juga dapat mengganggu kerja sama yang telah dilakukan oleh Indonesia sehingga kebijakan yang diambil pun perlu mengalami penyesuaian. Perubahan kepemimpinan ini sering terjadi di beberapa negara seperti Nauru, Vanuatu, dan Kepulauan Solomon. Survei yang dirilis oleh International Institute for Democracy and Electoral Assistance (2015) menunjukkan bahwa dari tahun 1968 hingga 2013 terdapat 125 peristiwa yang 
menyebabkan pergantian pemimpin di negara-negara seperti Kiribati, Papua Nugini, Kepulauan Solomon, Tuvalu, Vanuatu, dan Nauru dengan periode rata-rata pergantian 12-36 bulan. Adapun penyebabnya di antaranya adanya usulan mosi tidak percaya, pemilihan umum, pengunduran diri, kematian, dan lainnya.

Perubahan situasi politik yang terjadi di beberapa di Kepulauan Pasifik tentunya memiliki implikasi pada pendekatan atau strategi yang perlu diambil oleh pemerintah Indonesia, misalnya dengan Vanuatu. Sistem pemerintahan Vanuatu yang memungkinkan parlemennya untuk mengajukan mosi tidak percaya kepada Perdana Menteri berimbas pada seringnya pergantian pemimpin. Dalam kurun waktu 10 tahun, dari 2008 hingga 2018 terdapat 13 pergantian kepemimpinan di negara ini. Akibatnya, implementasi kebijakan luar negeri yang diambil oleh Indonesia perlu menyesuaikan dengan kebijakan-kebijakan yang diambil oleh setiap Perdana Menteri. Iklim persahabatan antara IndonesiaVanuatu misalnya terlihat pada tahun 2011 ketika pemerintah Vanuatu di bawah Perdana Menteri Sato Kilman menandatangani Perjanjian Kerjasama Pembangunan Bilateral. Perjanjian ini dianggap sebagai langkah yang penting dalam membangun hubungan yang konstruktif antar dua negara karena salah satu poin menyebutkan bahwa kedua negara sepakat untuk menghormati integritas dan kedaulatan wilayah. Dengan kata lain, perjanjian ini merupakan suatu upaya pemerintah Indonesia agar Vanuatu tidak mencampuri urusan yang terkait dengan kedaulatan Indonesia, khususnya masalah Papua. Beberapa negara di Kepulauan Pasifik, salah satunya Vanuatu merupakan negara yang lantang menyuarakan kemerdekaan Papua sehingga menimbulkan ancaman sendiri bagi Indonesia. Perjanjian pembangunan ini pun telah diratifikasi melalui penetapan Peraturan Presiden Nomor 31 tahun 2016. Tetapi, realisasi kesepakatan ini pun tidak berjalan mulus. Hasil dari perjanjian ini menimbulkan pertentangan dan ketidaksepakatan dalam tubuh pemerintahan Vanuatu di bawah Perdana Menteri yang baru, Moana Carcasses Kalosil (Maclellan 2015, 274). Dapat diamati bahwa pemerintah Indonesia memiliki hubungan yang cukup dekat dengan pemerintah Vanuatu di bawah kepemimpinan Sato Kilman. Misalnya pada tahun 2015 ketika Sato Kilman menjabat sebagai Menteri Luar Negeri, ia menyatakan keinginannya untuk membuka kedutaan besar di 
Jakarta (CNN Indonesia 2015). Apabila diamati dari urutan waktu yang terjadi, pernyataan ini dibuat setelah Indonesia memberikan bantuan kemanusiaan kepada Vanuatu untuk mengatasi dampak Siklon Pam. Sayangnya, pernyataan ini belum dapat terealisasikan ketika pada tahun berikutnya Sato Kilman terpilih kembali menjadi Perdana Menteri, ia justru kembali mendapatkan mosi tidak percaya. Kebijakan yang berubah-ubah akibat pergantian kepemimpinan di Vanuatu menuntut Indonesia untuk terus menyesuaikan kebijakannya guna menjalin relasi politik yang lebih baik.

Hubungan Indonesia dengan negara-negara di Kepulauan Pasifik sebenarnya lebih banyak disorot dari aspek politik ketimbang perspektif ekonomi (Bandoro 2014). Aspek politis ini erat kaitannya dengan sensitivitas beberapa negara di Kepulauan Pasifik terhadap masalah domestik Indonesia yang menyangkut isu hak asasi manusia di Papua yang disampaikan beberapa kali dalam forum PBB. Situasi ini kemudian menjadi faktor pendorong utama untuk mereposisi kebijakan luar negeri Indonesia di Kepulauan Pasifik. Negara-negara seperti Vanuatu dan Kepulauan Solomon secara lugas mendukung kemerdekaan Papua. Misalnya, pada sidang Dewan HAM PBB di Jenewa pada tahun 2014, PM Moana Carcasses Kalosil membawa isu pelanggaran HAM di Papua karena merasa memiliki ikatan persaudaraan Melanesia dan meminta kepada masyarakat internasional untuk memberikan perhatiannya terhadap masalah di Papua (Republik Vanuatu 2014a, 2). Pada tahun yang sama, Joe Y. Natuman, Perdana Menteri Vanuatu yang baru juga menaruh kepedulian yang besar pada penentuan nasib sendiri orang Papua seperti yang ia sampaikan di Sidang Majelis Umum PBB di New York pada September 2014 (Republik Vanuatu 2014b, 6). Berbagai serangan pernyataan terhadap Indonesia di Forum PBB tidak berhenti, pada tahun 2017 dalam Sidang Majelis Umum PBB di New York, PM Vanuatu dan Kepulauan Solomon kembali membawa isu dekolonisasi dengan menyatakan dukungannya terhadap kemerdekaan Papua (The Guardian 2017). Dukungan terhadap penentuan nasib sendiri masyarakat Papua ini pun diberikan oleh Perdana Menteri Tuvalu, Enele Sopoaga yang disampaikan pada Majelis Umum PBB ke-73 (The Guardian 2018). Di tingkat regional, Pemerintah Vanuatu juga pernah membuat rancangan Resolusi PBB untuk Papua Barat yang 
disampaikan pada Pertemuan Komite Forum Kepulauan Pasifik di Samoa pada tahun 2018 yang rencananya akan diserahkan sebagai resolusi dalam sidang Majelis Umum PBB 2019. Akan tetapi, hal ini dicegah oleh Australia, Fiji, dan Papua Nugini yang menyatakan keberatan terhadap draf rancangan pemerintah Vanuatu (The Vanuatu Daily Post 2018).

Perhatian besar terhadap isu Papua dianalisis terkait dengan spirit menentang kolonialisme yang menjadi faktor dalam pembentukan paradigma diplomasi baru negara-negara Kepulauan Pasifik (Fry dan Tarte 2015, 3). Menurut Fry dan Tarte (2015), diplomasi Pasifik baru adalah sebuah langkah mendasar yang dilakukan oleh negaranegara Kepulauan Pasifik yang independen untuk menciptakan sistem diplomatik poskolonial. Independensi dan kedaulatan yang menjadi nafas dalam diplomasi Pasifik merupakan elemen sentral dalam membentuk Forum Kepulauan Pasifik. Sebagai negara kecil, para pemimpin di Kepulauan Pasifik berkomitmen untuk meningkatkan peran dalam urusan global dengan membentuk forum di level regional dengan menyuarakan isu-isu yang menjadi perhatian mereka. Diplomasi Pasifik, sebagaimana yang diungkapkan oleh Fry dan Tarte (2015), merupakan suatu upaya negara-negara Kepulauan Pasifik untuk mengambil posisi dan terlibat dalam diplomasi global untuk menegosiasikan persoalan seperti perdagangan, pembangunan berkelanjutan, perubahan iklim, masalah nuklir, dekolonisasi, dan perikanan. Dalam hubungannya dengan Indonesia, masalah kemerdekaan Papua adalah salah satu agenda yang terus diperdebatkan oleh negaranegara di Kepulauan Pasifik. Masalah ini adalah bagian dari diplomasi Pasifik untuk mendorong dan menyelesaikan masalah dekolonisasi (Fry dan Tarte 2015).

Dukungan pada penentuan nasib sendiri terhadap orang Papua jelas merupakan ancaman terhadap Indonesia yang bersumber dari lingkup eksternal sebagaimana yang dijelaskan oleh Rosenau (1974). Pergantian kepemimpinan yang sering terjadi memengaruhi relasi politik negara-negara di Kepulauan Pasifik dengan Indonesia terutama karena kebanyakan pemimpin dari negara-negara Kepulauan Pasifik menaruh perhatian yang sangat besar terhadap isu Papua. Sementara itu, seperti yang diungkapkan oleh Nuechterlein (1976) kepentingan nasional 
merupakan suatu kebutuhan dan keinginan yang dimiliki oleh suatu negara berdaulat dalam kaitannya dengan negara berdaulat lainnya yang dapat mencakup kepentingan untuk melindungi negara dan warganya dalam menghadapi potensi ancaman yang bersumber dari luar. Untuk itu, masalah Papua merupakan masalah kedaulatan Indonesia yang dapat ditempatkan sebagai kepentingan nasional yang mencakup masalah kelangsungan hidup sehingga pemerintah Indonesia perlu mengambil sikap untuk beradaptasi dengan perubahan-perubahan yang terjadi di lingkup eksternal yang berpotensi mengancam struktur esensial Indonesia. Seperti yang diungkapkan oleh Rosenau (1974) bahwa perubahan yang terjadi di lingkungan eksternal bukanlah perubahan dalam seluruh sistem internasional tetapi hanya perubahan yang terjadi dalam lingkungan yang memiliki dampak signifikan terhadap negara yang melakukan tindakan adaptif. Dalam hal ini, perubahan-perubahan sikap negaranegara di Kepulauan Pasifik mendorong kebijakan yang adaptif dari pemerintah Indonesia untuk merespons potensi ancaman terhadap kesatuan negara.

Argumen lainnya yang mendukung mengapa kebijakan luar negeri Indonesia merupakan tindakan yang adaptif masih berkaitan erat dengan perkembangan yang terjadi di lingkup eksternal. Gerakan Persatuan Pembebasan untuk Papua Barat (United Liberation Movement for West Papua/ULMWP) yang merupakan gabungan daritiga gerakan Papua lainnya, yaitu Dewan Nasional Pembebasan Nasional Papua Barat (West Papua National Council for Liberation), Republik Federal Papua Barat, dan Parlemen Nasional Papua Barat melakukan manuver politik dengan mengajukan permohonan untuk mendapatkan keanggotaan penuh pada tahun 2015 lalu dalam Melanesian Spearhead Group (MSG), sebuah organisasi sub-regional di Kepulauan Pasifik (Maclellan 2015, 276). Menilik dari sejarahnya, pendirian MSG dilatarbelakangi oleh keinginan politik yang kuat untuk membebaskan negaranegara Melanesia dari kolonialisasi yang terjadi di Kepulauan Pasifik dengan demikian pengembangan ikatan budaya, politik, sosial, ekonomi, dan identitas antara orang-orang dan komunitas Melanesia menjadi cita-cita yang diwujudkan bersama melalui organisasi ini (Sekretariat MSG 2020). Untuk merespons gerakan ULMWP yang mengajukan aplikasi keanggotaan penuh di MSG, 
pemerintah Indonesia mengambil strategi dengan melakukan kunjungan diplomatik yang diwakili oleh Menteri Luar Negeri ke beberapa negara seperti Fiji, Kepulauan Solomon, dan Papua Nugini sebelum Konferensi Tingkat Tinggi (KTT) MSG. Sebulan sebelum KTT tersebut, Presiden Jokowi juga mengunjungi Papua Nugini untuk membahas tentang kerja sama energi dan sektorsektor lainnya serta mengumumkan pengampunan lima tahanan politik Papua (Maclellan 2015, 277). Setelah negosiasi ketat di KTT MSG, Indonesia diterima menjadi associate member sementara ULMWP sebagai pengamat. Menjadi associate member dalam MSG memberikan keuntungan sendiri bagi Indonesia. Jika secara konsensus seluruh anggota penuh MSG setuju maka Indonesia dapat terlibat dalam proses pengambilan keputusan dan dapat mengajukan hak untuk menyatakan pendapat. Selain itu, Indonesia juga memiliki akses terhadap dokumen yang bersifat rahasia (Kementerian Luar Negeri RI 2019). Tentu saja hak yang diberikan kepada Indonesia harus digantikan dengan kewajiban berupa kontribusi tahunan pada Sekretariat MSG (Kementerian Luar Negeri RI 2019). Akan tetapi, posisi Indonesia ini akan menjadi penting dalam menjaga kepentingan nasional terutama untuk memantau perkembangan masalah Papua sebagai salah satu agenda yang dibahas dalam MSG. Di sisi lain, keikutsertaan Indonesia dalam MSG akan membuka kesempatan antara Indonesia dengan ULMWP untuk dapat berdiskusi lebih lanjut (Wyeth 2018). Manuver politik yang dilakukan oleh ULMWP untuk menjadi anggota penuh MSG ini kemudian mendorong Indonesia untuk terlibat lebih aktif dalam organisasi sub-regional MSG dan berbagai forum lainnya di Kepulauan Pasifik untuk melawan dukungan dari diaspora kelompok separatis Papua. Pengajuan keanggotaan penuh ULMWP ini tentu saja menjadi potensi ancaman bagi Indonesia karena gerakan Papua tersebut dapat memiliki hak suara dalam proses pengambilan keputusan dalam MSG.

Perkembangan dalam lingkungan eksternal seperti perubahan kepemimpinan, diangkatnya masalah Papua di PBB, serta pergerakan ULMWP di MSG menjadi elemen yang memengaruhi kebijakan luar negeri Indonesia untuk bersikap adaptif terhadap negara-negara Kepulauan Pasifik. Di bawah kepemimpinan Joko Widodo, pendekatan yang dilakukan oleh Indonesia terhadap 
negara-negara di Kepulauan Pasifik, baik itu melalui cara bilateral maupun multilateral, menjadi lebih intensif dan proaktif. Di level multilateral, Indonesia berpartisipasi dalam berbagai forum multilateral seperti Forum Kepulauan Pasifik (PIF), MSG, Dialog Pasifik Barat Daya, Forum Pengembangan Kepulauan Pasifik (PIDF), dan Inisiatif Segitiga Terumbu Karang tentang Perikanan Terumbu Karang dan Keamanan Pangan (CTI-CFF). Realisasi kebijakan 'Look East' ini pun diperkuat dengan mekanisme diplomatik melalui penguatan hubungan bilateral antar Indonesia dengan negara-negara di Kepulauan Pasifik melalui kerja sama di beberapa sektor, seperti ketahanan pangan, pendidikan, tata pemerintahan yang baik, lingkungan, manajemen bencana, dan sosial budaya. Indonesia juga sudah memiliki hubungan diplomatik dengan 16 negara di kawasan Pasifik termasuk Australia, Selandia Baru, Papua Nugini, Fiji, Vanuatu, Kepulauan Solomon, Nauru, Tuvalu, Kiribati Samoa, Tonga, Kepulauan Marshal, Palau, dan Negara Federasi Mikronesia dan baru pada tahun 2019 lalu, Indonesia secara resmi membuka hubungan diplomatik dengan Kepulauan Cook dan Niue. Perwakilan Republik Indonesia di Pasifik tersebar di empat Kedutaan Besar Indonesia yang berlokasi di Canberra, Wellington, Port Moresby, dan Suva; empat Konsulat Jenderal berada di Melbourne, Sydney, Perth, dan Noumea; dan dua Konsulat di Darwin dan Vanimo (Kementerian Luar Negeri RI 2018a). Upaya untuk memperkuat hubungan bilateral juga ditunjukkan dengan kunjungan pertama Presiden Nauru pada tahun 2017 dan Presiden Federasi Mikronesia pada tahun 2018 membahas beberapa sektor untuk mengembangkan kerja sama ekonomi dan juga isu lingkungan.

Keterlibatan Indonesia di Kepulauan Pasifik pun ditunjukkan dengan memberikan berbagai bantuan baik dalam bentuk pembangunan kapasitas maupun kemanusiaan. Dalam pernyataan pers tahunan, Retno Marsudi mengatakan bahwa bantuan yang diberikan oleh Indonesia untuk memperkuat kehadirannya di Pasifik sebagai bentuk solidaritas ikatan Melanesia (Kementerian Luar Negeri RI 2018b). Negara-negara di kawasan Kepulauan Pasifik khususnya anggota MSG juga menjadi penerima manfaat utama dari Kerja Sama Selatan-Selatan dan Triangular. Sejak 1999, pemerintah Indonesia mengklaim bahwa 1.645 peserta dari wilayah Kepulauan Pasifik telah berpartisipasi dalam 194 
program peningkatan kapasitas yang diberikan oleh pemerintah (Kementerian Luar Negeri RI 2018a). Pada Maret 2019 lalu misalnya, pemerintah Indonesiajuga menyelenggarakan Indonesia South Pacific Forum (ISPF) yang dilanjutkan dengan Pacific Exposition untuk membuka potensi kerja sama perdagangan, investasi, dan turisme dengan negara-negara di Kepulauan Pasifik. Dalam hal kerja sama keamanan, Indonesia menjadi tuan rumah Pertemuan Kelompok Kerja Strategi Keamanan Regional MSG Pertama pada tahun 2017 untuk mencegah dan memberantas kejahatan lintas negara, membantu negara-negara anggota MSG dalam membuat kurikulum untuk pengembangan akademi polisi regional, dan mendukung negara-negara MSG dalam meningkatkan kontribusinya pada Operasi Pemeliharaan Perdamaian PBB dengan membentuk unit yang mirip dengan satuan polisi Indonesia (Jakarta Globe 2017). Tahun 2018 lalu, Indonesia-Fiji yang sudah memiliki hubungan diplomatik yang panjang dibandingkan negara-negara lainnya di Kepulauan Pasifik, mencoba memperluas kerja sama pada area strategis di bidang pertahanan dengan mengadakan pertemuan Menteri Pertahanan sebagai kelanjutan dari Nota Kesepahaman tentang Kerjasama Pertahanan yang ditandatangani pada September 2017 (The Diplomat 2018). Langkah yang diambil oleh pemerintah Indonesia dalam mendekati negara-negara di Kepulauan Pasifik, baik itu melalui mekanisme bilateral maupun multilateral dengan mencoba merambah area kerja sama dalam berbagai sektor yang dianalisis, tidak akan terlepas dari nuansa politis Indonesia yang memiliki kepentingan kuat dalam menjaga integrasi wilayah Papua dan untuk menangkal potensi ancaman yang bersumber dari negara-negara di Kepulauan Pasifik dalam forum-forum PBB.

Tindakan adaptif yang dilakukan oleh Indonesia bertujuan untuk meminimalisasi risiko demi mempertahankan struktur esensial negara seperti yang diungkapkan oleh Rosenau (1974) atau dengan kata lain, untuk memelihara kepentingan nasional. Walaupun bernuansa politis, Indonesia tetap mempertimbangkan aspek lain agar implementasi kebijakan 'Look East' ini juga memberikan manfaat secara ekonomi. Sebagai contoh, berdasarkan data yang dikeluarkan oleh World Integrated Trade Solution (WITS), dalam rentang 2015-2017, Papua Nugini dan Fiji merupakan mitra dagang terbesar di kawasan Kepulauan Pasifik di samping Australia dan 
Selandia Baru. Barang konsumen, produk makanan, dan bahan kimia merupakan contoh produk ekspor unggulan Indonesia. Nilai ekspor untuk barang konsumen dari Indonesia ke Fiji rata-rata mencapai 12-16 juta Dollar AS dalam rentang tahun 2015-2017 menurut data yang diperoleh dari WITS. Penyelenggaraan ISPF dan Pacific Exposition juga merupakan salah satu contoh lain keterlibatan Indonesia dari aspek ekonomi. Dengan penguatan kerja sama ekonomi antara Indonesia dengan negara-negara di Kepulauan Pasifik sebenarnya dapat memberikan peluang bagi Indonesia untuk menambah pasar non-tradisionalnya sekaligus dianalisis sebagai strategi yang dimainkan oleh Indonesia untuk merangkul negara-negara di Kepulauan Pasifik.

\section{Simpulan}

Di bawah kepemimpinan Joko Widodo selama satu periode dari tahun 2014-2019 pelaksanaan kebijakan luar negeri Indonesia atau yang lebih sering disebut sebagai "Look East Policy" mengalami kontinuitas dari para pendahulunya. Namun secara khusus, realisasi kebijakan ini memberikan perhatian lebih terhadap keterlibatan Indonesia yang mendalam di Kepulauan Pasifik baik itu melalui penguatan hubungan bilateral maupun di level multilateral. Perkembangan yang terjadi pada lingkup eksternal di Kepulauan Pasifik seperti pergantian kepemimpinan, isu Papua yang disuarakan oleh beberapa negara seperti Vanuatu, Kepulauan Solomon, dan Tuvalu diforum PBB, manuver politikyang dilakukan oleh ULMWP di organisasi seperti MSG atau pun pergerakan yang dilakukan oleh Vanuatu dalam Forum Kepulauan Pasifik terkait masalah HAM di Papua akhirnya mendorong tindakan yang adaptif dari Indonesia sebagai respons atas perubahan yang terjadi. Sikap yang diambil oleh pemerintah Indonesia seperti menjadi associate member dalam MSG, mitra pembangunan dalam Forum Kepulauan Pasifik dan Forum Pengembangan Kepulauan Pasifik misalnya, penguatan kerja sama bilateral, atau penyelenggaraan forum untuk membahas dan memperluas kerja sama ekonomi dianalisis sebagai tindakan adaptif sebagai upaya untuk merangkul negara-negara di Kepulauan Pasifik ini. Seperti yang dinyatakan oleh Rosenau (1974), kebijakan luar negeri yang 
diambil negara merupakan tindakan adaptif untuk menghadapi perubahan yang terjadi dengan tujuan mempertahankan kepentingan nasional. Merujuk pada pernyataan Rosenau (1974), kebijakan luar negeri yang diambil oleh pemerintah Indonesia dianalisis sebagai tindakan adaptif yang didorong oleh perkembangan di lingkungan eksternal, yaitu Kepulauan Pasifik sehingga memicu potensi ancaman bagi kedaulatan Indonesia. Untuk itu, apabila menggunakan pengelompokan yang dilakukan oleh Rosenau (1981), realisasi kebijakan Indonesia dapat disebut sebagai acquiescent adaptation atau dengan kata lain tindakan adaptif yang diambil merupakan respons terhadap perubahan eksternal.

\section{Referensi}

\section{Buku dan Bab dalam Buku}

Acharya, Amitav, 2014. Indonesia Matters: Asia's Emerging Democratic Power. Singapore: World Scientific.

Bandoro, Bantarto, 2014. Indonesia dalam Lingkungan Strategis yang Berubah. Yogyakarta: Graha Ilmu.

Cornock, Oliver (ed.), 2018. The Report: Indonesia 2018. Oxford: Oxford Business Group.

Fry, Greg, dan Sandra Tarte, 2015. "The New Pacific Diplomacy: An Introduction", dalam Fry, Greg dan Sandra Tarte (ed.), 2015 The New Pacific Diplomacy. Acton: Australian National University.

Hill, Christopher, 2016. Foreign Policy in the Twenty First Century Second Edition. London: Palgrave Macmillan.

Hudson, Valerie, 2014. Foreign Policy Analysis: Classic and Contemporary Theory Second Edition. New York: Rowman and Littlefield.

Kaikai, Abu Bakarr, 2015. Aid Policy and the Politics of Aid Opportunities and Challenges of the Rise of Chinese 
Indonesia's Foreign Policy in Pacific Island Countries during Joko Widodo Era 2014-2019: An Adaptive Action?

Foreign Aid in the Pacific Island Countries. Nordestedt: GRIN Publishing.

Maclellan, Nic, 2015. "Pacific Diplomacy and Decolonisation in the 21st Century", dalam Fry, Greg dan Sandra Tarte (ed.), 2015 The New Pacific Diplomacy. Acton: Australian National University.

Perwita, Anak Agung Banyu, dan Yanyan Yani, 2005. Pengantar Ilmu Hubungan Internasional. Bandung: PT Remaja Rosdakarya.

Poole, Avery, 2015. "The Foreign Policy Nexus: National Interests, Political Values and Identity", dalam Roberts, Christopher B., et al (eds.), 2015. Indonesia's Ascent: Power, Leadership, and the Regional Order. London: Palgrave Macmillan.

Rosenau, James N., 1966. "Pre-Theories and Theories of Foreign Policy”, dalam Farrell, R. Barry (ed.), 1966. Approaches to Comparative and International Politics. Evanston, Ill.: Northwestern University Press.

, 1974. Comparing Foreign Policy: Theories, Findings, and Methods. New York: Sage Publication. 1981.The Study of Political Adaptation: Essays on the Analysis of World Politics. New York: Nichols Publishing.

Snyder, Richard C., et al., 1954. Decision Making as an Approach to the Study of International Politics. Foreign Policy Project Series No. 3. Princeton: Princeton University Press.

Sprout, Harold, dan Margareth Sprout, 1956. Man-Milieu Relationship Hypotheses in the Context of International Politics. Princeton: Center of International Studies.

\section{Artikel Jurnal}

Anwar, Dewi Fortuna, 2010. "The Impact of Domestic and Asian Regional Changes on Indonesian Foreign Policy", 
Southeast Asian Affairs, 126-141.

Hannesson, Rognvaldur, 2008. "The Exclusive Economic Zone and Economic Development in the Pacific Island Countries", Marine Policy, 32(6): 886-897.

Nuechterlein, Donald E, 1976. "National Interests and Foreign Policy: A Conceptual Framework for Analysis and DecisionMaking", British Journal of International Studies, 2(3): 246-266.

Rosenau, James N, 1970. "Foreign Policy as Adaptive Behavior:

Some Preliminary Notes for a Theoretical Model", Comparative Politics, 2(3): 365-387.

Rosyidin, Mohamad, 2017. "Foreign policy in Changing Global Politics: Indonesia's Foreign Policy and the Quest for Major Power Status in the Asian Century." South East Asia Research, 25(2): 1-17.

Stringer, Kevin, 2006. "Pacific Island Microstates: Pawns or Players in Pacific Rim Diplomacy?”, Diplomacy \& Statecraft, 17(3): 547-577.

Weatherbee, Donald, 2017. "Indonesia's Foreign Policy in 2016: Garuda Hovering”, Southeast Asian Affairs, 163-176.

\section{Artikel Daring}

CNN Indonesia, 2015. "Vanuatu Berencana Buka Kedutaan Besar di Jakarta" [daring]. Dalam https://www.cnnindonesia. com/internasional/20150419173000-106-47729/ vanuatu-berencana-buka-kedutaan-besar-di-jakarta [diakses 20 Januari 2020].

Connely, Aaron L., 2014. "Indonesian Foreign Policy Under President Jokowi" [Daring]. Dalam https://www. lowyinstitute.org/publications/indonesian-foreign-policyunder-president-jokowi [diakses 1 Desember 2019].

Jakarta Globe, 2017. "Indonesia, Fiji Strengthen Relations on 
Indonesia's Foreign Policy in Pacific Island Countries during Joko Widodo Era 2014-2019: An Adaptive Action?

Trade, Security" [Daring]. Dalam https://jakartaglobe.id/ context/indonesia-fiji-strengthen-relations-trade-security [diakses 20 Januari 2020].

Marsudi, Retno L.P, 2019. "New Era of Indonesia-South Pacific Engagements" [Daring]. Dalam https://www. thejakartapost.com/academia/2019/o3/21/new-era-ofindonesia-south-pacific-engagement.html [diakses 21 Januari 2020].

The Diplomat, 2018. "What's next for Indonesia Fiji Military Ties?" [Daring]. Dalam https://thediplomat.com/2018/o8/ whats-next-for-indonesia-fiji-military-ties/ [diakses 25 Januari 2020].

The Guardian, 2017. "Melanesian Leaders Condemn UN for Turning 'A Deaf Ear' to West Papua Atrocities" [Daring]. Dalam https://www.theguardian.com/world/2017/ sep/24/melanesian-leaders-condemn-un-for-turninga-deaf-ear-to-west-papua-atrocities [diakses 20 Januari 2020].

2018. "Indonesia Accuses Vanuatu of Inexcusable Support for West Papua" [Daring]. Dalam https://www. theguardian.com/world/2018/oct/o3/indonesia-accusesvanuatu-of-inexcusable-support-for-west-papua [diakses 20 Januari 2020].

The Vanuatu Daily Post, 2018. "Vanuatu Presents Draft UN Resolution for West Papua to Pacific Islands Forum" [Daring]. Dalam http://dailypost.vu/news/vanuatupresents-draft-un-resolution-for-west-papua-to-pacific/ article_f57f6701-d92b-5d82-b271-1d18fab8obb3.html [diakses 1 Februari 2020].

Wyeth, Grant, 2018. "At Melanesian Spearhead Group, the Question of West Papuan Membership Lingers" [Daring]. Dalam https://thediplomat.com/2018/02/at-melanesianspearhead-group-the-question-of-west-papuanmembership-lingers/ [Diakses 30 Maret 2020]. 
Sekretariat MSG, 2020. "About Us" [Daring]. Dalam https://www. msgsec.info/about-msg/ [Diakses 1 April 2020].

Kementerian Luar Negeri RI, 2019. "Kerja Sama Regional: Melanesian Spearhead Group" [Daring]. Dalam https:// kemlu.go.id/portal/id/read/128/halaman_list_lainnya/ melanesian-spearhead-group-msg [Diakses 1 April 2020].

\section{Dokumen Resmi}

Badan Perencanaan Pembangunan Nasional (Bappenas), 2014. Rencana Pembangunan Jangka Menengah Nasional 2015-2019. Jakarta: Bappenas.

Kementerian Luar Negeri RI, 2015. Rencana Strategis 2015-2019. Jakarta: Kementerian Luar Negeri RI.

Peraturan Presiden Nomor 31 Tahun 2016 tentang Perjanjian Antara Republik Indonesia dan Republik Vanuatu tentang Kerangka Kerja Sama Pembangunan, 2016. Jakarta: Setkab.

Republik Vanuatu, 2014a. "Statement by The Right Honorable Moana Katokai Kalosil Carcasses Prime Minister of The Republic of Vanuatu Before The High Level Segment of The Fifth Session of The Human Rights Council.” Transformative Post-2015 Development Agenda." Statement delivered by Hon. Joe Y. Natuman Prime Minister of Republic Vanuatu at the 69th Session of the United Nations General Assembly, New York, September 2014.

Undang-Undang Republik Indonesia Nomor 37 Tahun 1999 tentang Hubungan Luar Negeri, 1999. Jakarta: DPR 
Indonesia's Foreign Policy in Pacific Island Countries during Joko Widodo Era 2014-2019: An Adaptive Action?

\section{Lain-lain}

International Institute for Democracy and Electoral Assistance, 2015. "Policy Brief: Leadership Turnover in the Pacific Islands: A Preliminary Analysis", International IDEA, November 2015.

Kementerian Luar Negeri RI, 2018a. "Diskusi Kelompok Terarah tentang Potensi Kerjasama Ekonomi Antara Republik Indonesia dan Wilayah Pasifik Selatan”. Bandung, 20 Desember 2018.

Kementerian Luar Negeri RI, 2018b. Pernyataan Pers Tahunan Menteri Luar Negeri Republik Indonesia Tahun 2018 [Pernyataan Pers], dikeluarkan 9 Januari 2018. 